\title{
Entrepreneurial mindset of information and communication technology firms
}

\author{
M.J. Scheepers \\ Department of Business Management \\ University of Stellenbosch \\ Stellenbosch, South Africa \\ mjs@sun.ac.za
}

Limited research focuses on the entrepreneurial mindset of information and communication technology (ICT) firms, despite the opportunities in and importance of this sector for economic growth. In this article, the entrepreneurial mindset of ICT firms is described by using three indicators: entrepreneurial orientation, e-business initiatives and a supportive organizational climate. Data were obtained using structured telephone interviews with 144 ICT firms. The findings indicate that the three indicators of an entrepreneurial mindset are associated and can be linked to performance. It is recommended that managers create a supportive climate for entrepreneurship by offering rewards, empowering employees and providing leadership and support for initiatives.

Key words: Entrepreneurial mindset, information entrepreneurship, entrepreneurial orientation, initiatives, organizational climate

Received 5 August 2008

\section{Contents}

1. Introduction

2. Entrepreneurial mindset

2.1 Entrepreneurial orientation

2.2 E-business initiatives

2.3 Supportive organizational climate

3. Methodology: empirical survey

3.1 Sample

3.2 Measures

3.3 Data analyses

4. Findings

4.1 Sample profile

4.2 Entrepreneurial mindset

4.3 Inter-relationship between indicators of entrepreneurial mindset

5. Recommendations and conclusions

6. Acknowledgements

7. References 


\section{Introduction}

Innovation has become a primary differentiator of organizational competitiveness, rendering it a source of sustained long-term prosperity (Drucker 2007:3). Furthermore, the potential of entrepreneurial strategies to create innovations, economic growth and wealth has been emphasized in recent years, especially for firms operating in turbulent environments such as the information and communication technology (ICT) industry (Antoncic and Hisrich 2001, Dutta and Mia 2007; Mbeki 2002; NRF 2004; Zahra and Bogner 1999). Entrepreneurial feats in the ICT industry, such as Google, Amazon, Thwate and others, have captured the imagination of many aspiring information entrepreneurs. However, when the dot.com bubble burst and many Internet start-ups failed, it became clear that, despite the tremendous potential in the ICT industry, healthy business principles still apply (Malone 2001:11).

The entrepreneurship and innovation management body of knowledge has grown significantly in recent years (Busenitz, West, Shepherd, Nelson, Chandler and Zacharakis 2003; Sharma and Chrisman 1999; Shane and Venkataraman 2000; Zahra 2007). Research has focused on the individual, the firm, and the public enterprise in terms of the entrepreneurial process as well as the benefits of entrepreneurship and innovation for the economies of countries (Birch 1987; Morris, Kuratko and Covin 2008; Pinchot 1999; Zahra 1991, 1993). Specifically, studies on entrepreneurship of firms have focused on the internal environment within firms (Antoncic and Hisrich 2001; Damanpour 1991; Hornsby, Kuratko and Zahra 2002) as well as the influence of the external environment on entrepreneurial activities (Zahra 1991, 1993; Zahra and Covin 1995). However, the discipline has been criticized for being too reliant on developed country data to inform theory development (Hills and LaForge 1992:33; Knight 1997:213; Moodley 2002:67). Little seems to be known about the entrepreneurial nature of established firms in developing countries. Furthermore, the Global Entrepreneurship Monitor studies (Minniti, Bygrave and Autio 2005; Scheepers 2005) have indicated that many South African firms are not innovative and fail to use new technologies to satisfy the changing needs of their consumers.

The importance of the ICT industry is reflected in its role as one of the most important drivers in boosting efficiency and productivity in today's fast changing global economy. Enabling ICT infrastructure permits countries to improve resource allocation, boost growth prospects (Dutta and Mia 2007) and offer many opportunities for innovation and entrepreneurship (ISETT Seta 2007). The ICT sector has been identified in the National Research and Development Strategy (Department of Science and Technology 2002) as one of the 'lead sectors' in innovation and economic growth (Mbeki 2002). Despite the importance of entrepreneurship and innovation in this industry in South Africa, little research has so far focused on information entrepreneurship, especially within established enterprises (Scheepers and Hough 2004:2). This article is an attempt to address this research gap by describing the entrepreneurial mindset of ICT firms operating in South Africa. Within the turbulent technological environment, ICT firms need to be agile, flexible, innovative and proactive, in other words they need to adopt an entrepreneurial mindset (Morris et al. 2008:325).

In this article, the purpose is to describe the entrepreneurial mindset of ICT firms operating in South Africa and applied it to the e-business space. The e-business space in this article refers to e-business products, services, processes and strategies that firms pursue. Therefore, the research on which this article is based aimed to:

- Identify the indicators and underlying dimensions of an entrepreneurial mindset

- Describe the entrepreneurial mindset of South African ICT firms 
- Make recommendations based on the findings for managers and practitioners.

\section{Entrepreneurial mindset}

An entrepreneurial mindset describes the innovative and energetic pursuit of opportunities and facilitates action aimed at exploiting these opportunities (Senges 2007). McGrath and MacMillan (2000) argue that strategists/firms should adopt an entrepreneurial mindset to sense opportunities, mobilize resources and exploit opportunities. On an individual level, an entrepreneurial mindset is a life philosophy, while on an organizational level it forms an intangible part of a firm's culture and climate. Before entrepreneurial mindset as concept is assessed, it is important to define the term entrepreneurship. The definition that captures a wide number of nuances of the entrepreneurial process is that by Stevenson and Jarillo (1990:20). These authors describe entrepreneurship as a 'process by which individuals either on their own or inside organizations - pursue opportunities without regard to the resources that they currently control.' This definition emphasizes the following:

- Entrepreneurship is not a single act, but a process.

- Entrepreneurship occurs in various contexts such a start-up firm, but also in established firms.

- Entrepreneurship is opportunity-driven and not constrained by a lack of resources.

- Entrepreneurial behaviour is preceded by an entrepreneurial philosophy or entrepreneurial mindset.

Although inherently intangible, the entrepreneurial mindset of a firm can be assessed by three indicators:

- The entrepreneurial orientation of the firm;

- the number of initiatives implemented in a firm; and

- the internal organizational culture and how it supports entrepreneurial behaviour of employees inside the firm.

\subsection{Entrepreneurial orientation}

Entrepreneurial orientation (EO) refers to the strategic mindset of a firm and encompasses the processes, practices and decision-making activities that facilitate the pursuit and exploitation of opportunities (Dhilwayo and Van Vuuren 2007:124; Lumpkin and Dess 1996:137). Most researchers have built on the work of Miller (1983) and Covin and Slevin (1989) and studied EO, using three key dimensions that include the propensity to innovate, take risks and pursue opportunities in a pro-active manner. Conversely, Lumpkin and Dess (1996) argue that not three, but five dimensions should be used to measure entrepreneurship, namely autonomy, competitive aggressiveness, pro-activeness, innovativeness and risktaking. In contrast with their view, in this article the author argues that autonomy is an internal factor that influences the innovation supportive climate in a firm. In a similar vein, competitive aggressiveness forms part of the pro-activeness sub-dimension. Researchers who support this view include Morris, Schindehutte and Allen, (2005:728) as well as Kreiser, Marino and Weaver (2002).

Innovativeness, the first dimension of EO, refers to the ability to generate ideas that will culminate in the production of new products, services and technologies. Risk-taking, the second dimension, involves the determination and courage to make resources available for projects that have uncertain outcomes, in other words, those that involve risk. Attempts are made to manage these risks by researching a market, recruiting and employing skilled staff. 
Pro-activeness, the third dimension, indicates the stance of top management towards opportunities, encouragement of initiative, competitive aggressiveness and confidence in pursuing enhanced competitiveness (Antoncic and Hisrich 2001:497-499; Kreiser et al. 2002; Morris 1998:32-35).

Entrepreneurial orientation of a firm is not a discrete variable, but rather a continuous variable, changing in terms of its intensity. Therefore entrepreneurial behaviour may differ in terms of its innovativeness, pro-activeness and risk-taking dimensions. This variation can be visualized as opposites on a conceptual continuum, where one extreme would represent conservative behaviour and another extreme would represent entrepreneurial behaviour (Barringer and Ireland 2008:16).

Some sceptics may question the value of the EO construct, but a number of studies show a positive relationship between EO and improved financial performance (Goosen 2002, Wiklund 1999; Zahra 1991, 1993; Zahra and Covin 1995). These studies emphasize that the link between EO and financial performance as well as EO and value creation increases over time, since entrepreneurial activities contribute to the long-term performance of the enterprise (Antoncic and Hisrich 2001; Erasmus and Scheepers 2008; Goosen, De Coning and Smit 2002).

It is expected that higher levels of innovativeness and proactiveness and moderate levels of risk-taking should lead to ICT firms generating a higher number of entrepreneurial ebusiness initiatives (Morris and Kuratko 2002:46).

\subsection{E-business initiatives}

Initiatives are seen as 'the outcome of a process by which individuals inside organizations identify and pursue an opportunity to create future goods and services, without regard to the resources they currently control, culminating in the approval of that opportunity' (Wielemaker 2003:37). In the entrepreneurship literature, initiatives can result in product, service or process innovations. Another outcome of the entrepreneurial process could be that a firm pursues a new market segment, that is, new business.

E-business initiatives - as an outcome of the entrepreneurial process - can be assessed by examining the frequency or number of times these initiatives come to fruition. Morris and Sexton (1996:6-7) argue that a firm is capable of producing a number of entrepreneurial initiatives over time. Implementation of a single initiative does not constitute a high frequency of initiatives. However, multiple initiatives, such as the development of a new ebusiness system and additional services suggest higher frequency levels (Covin and Slevin 1991; Kreiser et al. 2002; Zahra 1993). In other words, some firms may have a greater tendency to behave entrepreneurially than others.

Covin and Slevin (1991:20-23) view firms with an entrepreneurial mindset as those in which initiative patterns recur. Davidsson (1989:211-212) uses the term 'continued entrepreneurship' to describe a tendency he found among individuals and firms to continuously pursue novel business opportunities. Other authors (Covin and Slevin 1991, Kreiser et al. 2002; Morris and Sexton 1996; Zahra 1993:47) concur that a growth orientation forms the defining characteristic of an entrepreneurial mindset. Therefore a firm that produces a single entrepreneurial business over a long period of time, such as a cyber procurement system, is not considered to have a particularly entrepreneurial mindset. Rather, a continued effort to develop new initiatives, such as new e-business products, services, markets and processes is indicative of firms having a highly entrepreneurial mindset. The employees of firms with supportive organizational cultures tend to produce larger numbers of initiatives. 


\subsection{Supportive organizational climate}

An entrepreneurial mindset is invariably captured by the shared perception employees hold of the firm's internal climate (Morris and Kuratko 2002:156). Climate can be defined as 'the relatively enduring quality of the total organisational environment that is perceived by organisational members, influences their behaviour and can be described in terms of the values of a particular set of characteristics of the environment' (Tagiuri and Litwin 1968:25). Implicit in this definition is the fact that organizational climate has a holistic nature, that it is relatively permanent and difficult to change, and that it has its roots in the firm's system of beliefs, values and assumptions (Denison 1996:268). A number of empirical studies in the entrepreneurship literature (Burgelman 1983, 1984; Elenkov, Judge and Wright 2005; Hornsby et al. 2002) have demonstrated that the organizational climate within a firm influences the type of entrepreneurial activities a firm pursues.

Salient indicators of a supportive organizational culture are organizational leadership and support, empowered employees, rewards given for entrepreneurial behaviour as well as resource availability, especially time and cross-functional interaction within the organization. These factors create an organizational climate, which shapes the view of managers and employees and their interest in pursuing entrepreneurial activities (Kuratko, Montagno and Hornsby 1990).

\subsubsection{Organizational leadership and support}

Organizational leadership and support for entrepreneurial activities have been identified by numerous researchers as vital to ensure the success of entrepreneurial activities (Chandler, Keller and Lyon 2000; Damanpour 1991; Morris and Kuratko 2002:358). Brown and Eisenhardt (1995:372-375) emphasize the considerable role top management plays in the product development process, especially as regards the timely and successful introduction of a new product. Organizational leadership and support may take various forms at top management level, such as sharing a vision for the future, communicating a distinctive product concept, giving approval to a project team to proceed with a new idea, and providing the necessary resources (Srivistava and Lee 2005:465).

Middle managers also provide leadership and can support employees by championing innovative ideas, recognizing people who articulate ideas and providing needed resources or expertise (Hornsby et al. 2002:255-256). Without leadership and support, entrepreneurial individuals will struggle to implement their initiatives, even if they are able to generate ideas. Leadership within the firm therefore plays a key role in creating an entrepreneurial climate, thus providing room for individuals to participate in organizational decision making.

\subsubsection{Employee empowerment}

Employee empowerment, worker participation, creativity and shared responsibility characterize supportive climates, reflecting an entrepreneurial mindset (Ngo and Lau 2004). Such climates facilitate entrepreneurship by increasing employees' awareness, commitment, involvement and autonomy (Damanpour 1991). Empowering of employees entails encouraging and authorizing workers to take initiative to improve business activities, such as cost-saving ideas, improving product quality and customer service, among other things (Anandji 2006). Empowerment is linked to autonomy, which Lumpkin and Dess (1996:140) see as the freedom individuals and teams enjoy, enabling them to exercise their creativity and champion promising ideas needed for entrepreneurship to occur (Lumpkin and Dess 1996:140). In other words, autonomous individuals are empowered to make and execute decisions needed to complete entrepreneurial projects. Especially employees in the ICT environment need to be empowered, since they function as knowledge workers. Drucker 
(2007:4) regards knowledge workers as employees who deal with information, ideas and expertise. Knowledge workers are part of the so-called 'knowledge economy', where the emphasis is on creativity and innovation, rather than on maintaining the status quo. A proactive management style is needed to enable knowledge workers to thrive (Morris and Kuratko 2002:260).

Gemünden, Salomo and Krieger (2005:371-372) found that even though higher autonomy within new projects does not lead to significantly higher project success, autonomy is, among other factors, a necessary condition for project success. In supportive climates, employees are willing to take risks and management tolerates failure and mistakes employees make when innovating (Hornsby et al. 2002:257-258), yet, to reinforce behaviour, firms need to reward initiatives.

\subsubsection{Reward systems}

Organizations should provide rewards and recognition for creative work and performance accomplishments. Chandler et al. (2002:62) found that reward systems have a significant impact on innovative activity, since such systems may reinforce innovative activities or the system may discourage initiatives by rewarding other behaviours. Innovative firms are characterized by providing rewards subject to performance, offering challenges, increasing responsibilities and making the ideas of innovative people known to others in the organizational hierarchy (Kuratko and Hodgetts 2004:120-125). However, just providing rewards, without allocating other resources to initiatives, may doom entrepreneurial projects to failure.

\subsubsection{Resource availability}

Resource availability for stimulating initiatives is a crucial dimension for creating a supportive organizational climate. The availability of slack resources could encourage experimentation and risk-taking behaviours (Damanpour 1991:363). Furthermore, employees can assess the importance of innovation in the firm and the intrinsic value of entrepreneurial projects based upon the level of resource allocation. A lack of resources such as time, materials and information may lead to reduced commitment to assigned goals (Chandler et al. 2002:62).

Time available for employees to work on initiatives is seen as key to creating a supportive climate (Hornsby et al. 2002:258). For example, one of the most entrepreneurial ICT companies, Google, allows its employees to allocate up to $20 \%$ of their time on pursuing new initiatives (Vise 2005:114). In this research, time availability was assessed as a proxy for resource availability. The final dimension, identified by Hornsby et al. (2002:259), that forms part of a supportive climate is cross-functional interaction within a firm.

\subsubsection{Cross-functional interaction}

Cross-functional interaction between various departments within a firm becomes more difficult as enterprises evolve, since formal structures and processes are required to create order and logic for firm operations. However, the danger in this formalization process is that firms may become bureaucratic, and bureaucracy tends to inhibit entrepreneurial activities. Nevertheless, there are alternative options to enhance entrepreneurial performance.

Morris and Kuratko (2002:205) argue that organic organizational structures are needed to facilitate initiatives. Organic structures are flexible and consist of groups of trained specialists from different work areas who collaborate to solve problems. Organic structures are flat and informal, facilitating communication and teamwork (Govender 1998:11). Within 
organic structures, cross-functional interaction is encouraged. This provides a climate in which entrepreneurial problems can be solved by allowing innovative ideas to be generated, evaluated and implemented (Hornsby et al. 2002:260).

To summarize, the entrepreneurial mindset of an ICT firm can be assessed by analysing their $\mathrm{EO}$, the number of e-business initiatives and how supportive the organizational climate is of entrepreneurial behaviour.

\section{Methodology: empirical survey}

The purpose of this article is to describe the entrepreneurial mindset of South African ICT companies. To achieve this objective, a cross-sectional telephone survey focused on a sample of ICT firms was conducted.

\subsection{Sample}

ICT firms were identified employing IT Web's member list, since this list is also used in the annual e-business survey. Therefore, these firms are familiar with the topic of e-business innovation. Respondents who are aware and informed are able to provide more thoughtful answers (Zahra 1991:272). A total of 424 firms appeared on the list. All firms on the list were contacted and asked to participate. Responses from 144 firms were obtained, which represents a response rate of 34\%, comparable to other studies of this nature (Goosen 2002; Yu and Cooper 1983).

Data were collected between August and October 2005 by means of telephone interviews with the chief executive officer (CEO) or sales manager of the responding firm. These respondents were chosen since their positions provided them with a unique and comprehensive view of the e-business environment and entrepreneurial activities in their firms.

\subsection{Measures}

Based on the indicators identified in the literature review, a questionnaire was drawn up. The questionnaire assessed the entrepreneurial mindset of ICT firms by gauging their entrepreneurial orientation, e-business initiatives implemented and the organizational climate of respondents. In addition, the e-business performance of firms, firm size (assessed by the number of employees) and the number of years the firm had been in existence was also recorded. Scales and items from existing measurement instruments (Hornsby et al. 2002; Knight 1997; Morris and Sexton 1996) were used, adapted and supplemented where necessary to capture the indicators and their underlying dimensions.

Entrepreneurial orientation was assessed, using the ENTREscale (Knight 1997; Miller and Friesen 1983), which had been tested cross-culturally. The number of $e$-business initiatives implemented by a firm was assessed, using an adapted version of the Entrepreneurial Performance Instrument (EPI) questionnaire, developed by Morris and Sexton (1996). The dimensions of this indicator were related to new e-business products, services and process introductions. Since this research viewed new business development as a part of the initiative indicator, the questionnaire was expanded to include this dimension as well. Respondents were asked to rank the degree of the e-business initiative improvements over the past two years, compared to the previous five years, relative to their own performance and the performance of their competitors on a 9-point Likert scale with 1 being 'significantly less' and 9 being 'significantly more'. They were also asked to indicate the degree of change in 
their products (improvements or 'new-to-the-world' products). The mean of three items provided an indication of each initiative dimension.

The supportive organizational climate was assessed using the Corporate Entrepreneurship Assessment Instrument (CEAI) by Hornsby et al. (2002), which had been tested in the South African context (Adonisi 2003:93-135). Finally, the performance of ICT firms was assessed, using an index based on internal subjective assessment of a firm's performance. The statements regarding subjective performance were related to the firm's performance relative to its historical performance and its performance relative to that of their competitors.

The questionnaire was pre-tested in interviews with 41 middle managers of ICT firms in the Gauteng area, and adapted where necessary. During the telephone survey, a structured interview, based on the questionnaire, was administered. Generally, the questionnaire contained statements and respondents had to indicate their agreement or disagreement with statements on a 9-point Likert scale with 1 being 'strongly disagree' and 9 being 'strongly agree'. The nine-point scale was used since it was relatively easy for respondents to visualize a nine-point scale during the telephone interview.

The internal consistency reliability of the theoretical indicators and their underlying dimensions were calculated, using Cronbach alpha coefficients, as shown in Table 1.

Table 1 Summary of Cronbach alpha coefficient values of entrepreneurial mindset

\begin{tabular}{|c|c|}
\hline Indicators and dimensions & $\begin{array}{l}\text { Cronbach Alpha } \\
\text { coefficient values }\end{array}$ \\
\hline Entrepreneurial orientation & 088 \\
\hline Innovativeness & 0,80 \\
\hline Risk-taking & 0,88 \\
\hline Proactiveness & 0,77 \\
\hline E-business initiatives & 0,79 \\
\hline Product & 0,68 \\
\hline Service & 0,74 \\
\hline Process & 0,77 \\
\hline Business & 0,67 \\
\hline Supportive climate & $\mathbf{0 , 7 0}$ \\
\hline Organizational leadership and support & 0,92 \\
\hline Empowered employees & 0,85 \\
\hline Rewards & 0,88 \\
\hline Time availability & 0,47 \\
\hline Cross-functional cooperation & 0,70 \\
\hline
\end{tabular}

The three indicators entrepreneurial orientation, e-business initiatives and supportive climate Cronbach Alpha coefficients were 0,88, 0,79 and 0,77 respectively. These coefficients would appear to satisfy Nunally's (1978) suggested minimum criterion for internal reliability. Coefficients lower than 0,5 are regarded as questionable, coefficients close to 0,70 as acceptable and coefficients of 0,80 as good (Sekaran 1992). The Cronbach alpha coefficient for time availability was 0,47 ; therefore this dimension was omitted from subsequent analyses. 


\subsection{Data analyses}

Data was analysed using Statistica 7.1 (Statsoft 2007). Below, the sample is described, using frequency tables; thereafter the entrepreneurial mindset of ICT companies is portrayed, using the mean standard deviation and coefficient of variation statistics. Finally, the associations between the various dimensions of entrepreneurial mindset are described, using correlation analysis.

\section{Findings}

The findings presented in this section firstly describe the sample; secondly present descriptive statistics of entrepreneurial mindset and its indicator dimensions and, thirdly, examine the relationships between these dimensions to provide an overview of the entrepreneurial mindset of firms.

\subsection{Sample profile}

The sample of firms that participated in the study consisted of 144 ICT firms, operating in South Africa. Figure 1 illustrates that most of the companies in the sample (48\%) employed less than 100 employees. The ISETT Seta's analysis of the ICT industry also confirms that most ICT firms do not employ a large number of employees (ISETT Seta 2007). Some studies suggest that small firms are especially suited to entrepreneurial behaviour and change (Gudmundson, Tower and Hartman 2003:1). Only 17\% of companies in the sample employed 1000 and more employees.

Figure 1 Bar chart representing the size of ICT companies

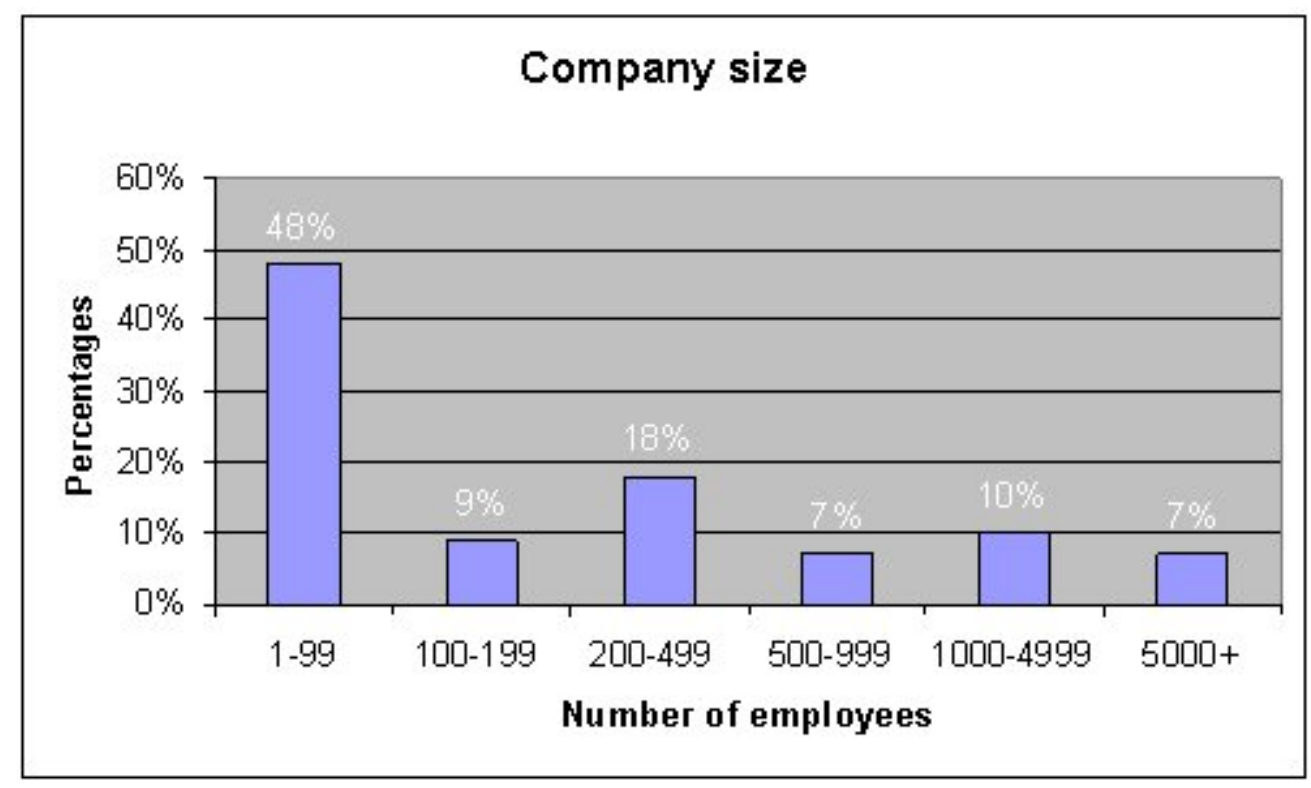

Figure 2 shows that most of the companies in the sample (46\%) had been in existence for between 7 and 15 years, and could therefore be considered established enterprises. Less than a third of the companies $(30 \%)$ had existed for six years and less, while a quarter $(25 \%)$ of the companies had existed for longer than 16 years.

Figure 2 Bar chart representing the number of years companies were in existence 


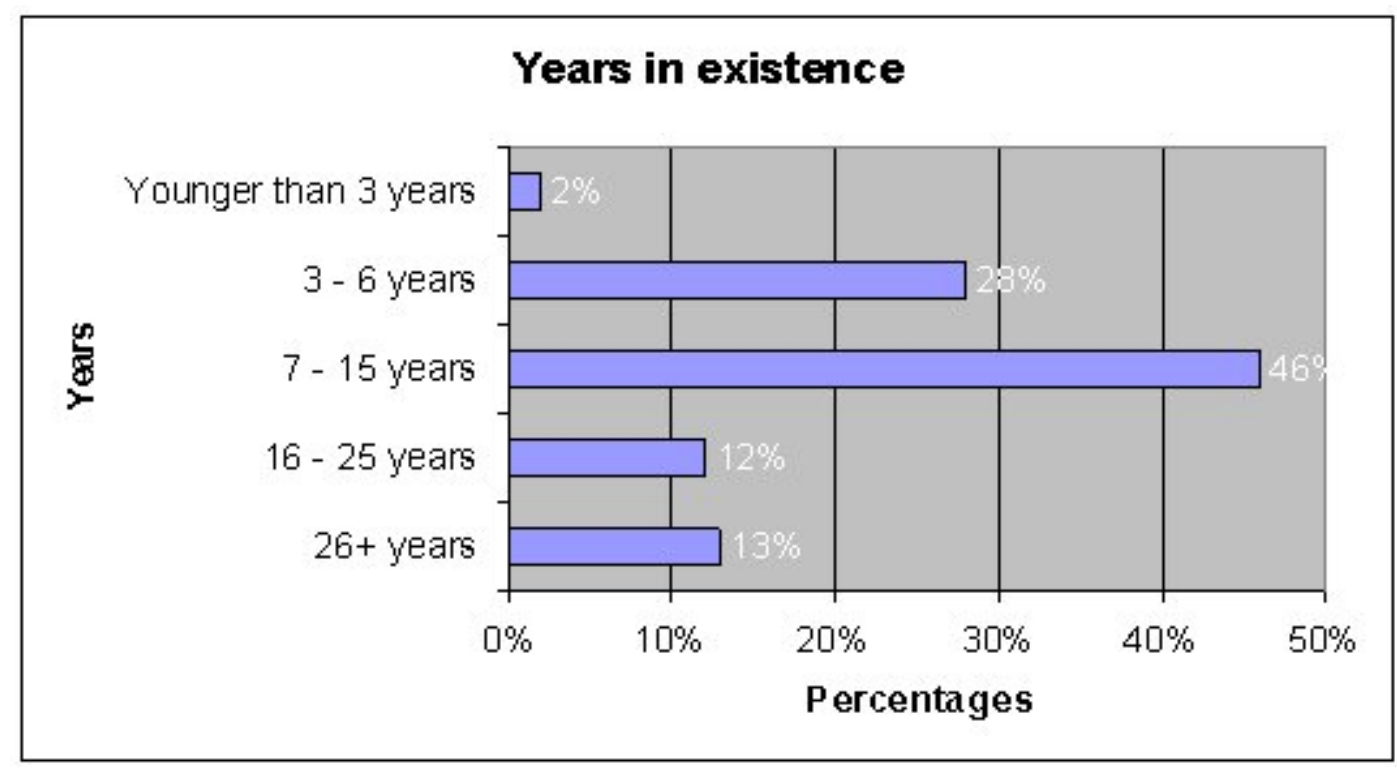

\subsection{Entrepreneurial mindset}

Table 2 contains descriptive statistics of the indicators of firms' entrepreneurial mindset, describing the EO, e-business initiatives, supportive climate and also the performance of firms, using the mean median, standard deviation and coefficient of variation to describe the data. The firms in the sample answered all questions, except those pertaining to initiatives, since it is possible for a firm to implement product initiatives only and not any process initiatives as well. Respondents only answered those questions which applied to their own situations, thus the number of respondents $(n)$ per initiative differs.

Table 2 Descriptive statistics of the indicators of entrepreneurial mindset

\begin{tabular}{|l|c|c|c|c|}
\hline Variables & Mean & Std dev & Coef var & $\boldsymbol{N}$ \\
\hline & & & & \\
\hline Entrepreneurial orientation & $\mathbf{5 , 9 1}$ & $\mathbf{1 , 1 9}$ & $\mathbf{2 0 , 0 7}$ & $\mathbf{1 4 4}$ \\
\hline Innovativeness & 6,12 & 1,60 & 26,22 & 144 \\
\hline Pro-activeness & 6,33 & 1,40 & 22,09 & 144 \\
\hline Risk-taking & 5,30 & 1,76 & 33,22 & 144 \\
\hline & & & & \\
\hline Initiatives & $\mathbf{5 , 8 3}$ & $\mathbf{1 , 2 5}$ & $\mathbf{2 1 , 4 0}$ & $\mathbf{1 1 2}$ \\
\hline Product & 6,09 & 1,64 & 26,98 & 128 \\
\hline Service & 5,75 & 1,63 & 28,32 & 133 \\
\hline Process & 5,67 & 1,58 & 27,77 & 126 \\
\hline Business & 5,21 & 2,25 & 43,15 & 144 \\
\hline & & & & \\
\hline Supportive climate & $\mathbf{5 , 7 0}$ & $\mathbf{0 , 7 3}$ & $\mathbf{1 2 , 9 0}$ & $\mathbf{1 4 4}$ \\
\hline Organizational leadership and support & 6,49 & 1,26 & 19,41 & 144 \\
\hline Empowered employees & 6,76 & 1,21 & 17,83 & 144 \\
\hline Rewards & 7,30 & 1,35 & 18,42 & 144 \\
\hline Cross-functional cooperation & 3,27 & 1,51 & 46,20 & 144 \\
\hline & & & &
\end{tabular}






\subsubsection{Entrepreneurial orientation}

ICT companies score relatively high on overall EO with a score of 5,91 on a 9-point scale. Of the three dimensions, respondents scored the highest on pro-activeness $(6,33)$ and the lowest on risk-taking $(5,30)$. It would appear that overall the EO of ICT companies is consistent with what the literature terms an 'entrepreneurial firm' (Morris and Kuratko 2002), showing higher scores on pro-activeness and innovativeness and a moderate risk-taking orientation.

\subsubsection{Initiatives}

The overall score obtained for the sample was 5,83, in terms of the number of initiatives generated in comparison to their previous performance, competitors and the degree of newness. This score is above the mid-point $(4,5)$ on a nine-point scale. The level of ebusiness initiatives implemented by respondents reflects that constant entrepreneurial activities take place in the ICT sector, as would be expected in such a dynamic, technological environment. As shown in Table 2, not all respondents were active in each of the different types of initiatives. Some ICT firms did not focus on product initiatives, while others did not focus on process initiatives; therefore not all firms that participated in the survey answered these questions.

Respondents' answers showed that they were most active when it came to new e-business product initiatives, with a score of 6,09 , while service $(5,75)$ and process $(5,67)$ initiatives were also frequently generated. The lowest activity was recorded on the new business initiatives dimension $(5,21)$. The reason for this could be that most firms in the sample were small and medium-sized firms, with limited employees and other resources. These firms may therefore need to focus their limited resources on exploiting opportunities in their current markets.

\subsubsection{Supportive organizational climate}

In general, respondents indicated that the climate in which they work is relatively supportive of entrepreneurial behaviour, with a score of 5,70. When examining the separate dimensions of the supportive climate, rewards $(7,30)$ was the dimension that featured most strongly.

Figure 3 Radar diagram of supportive climate factors 


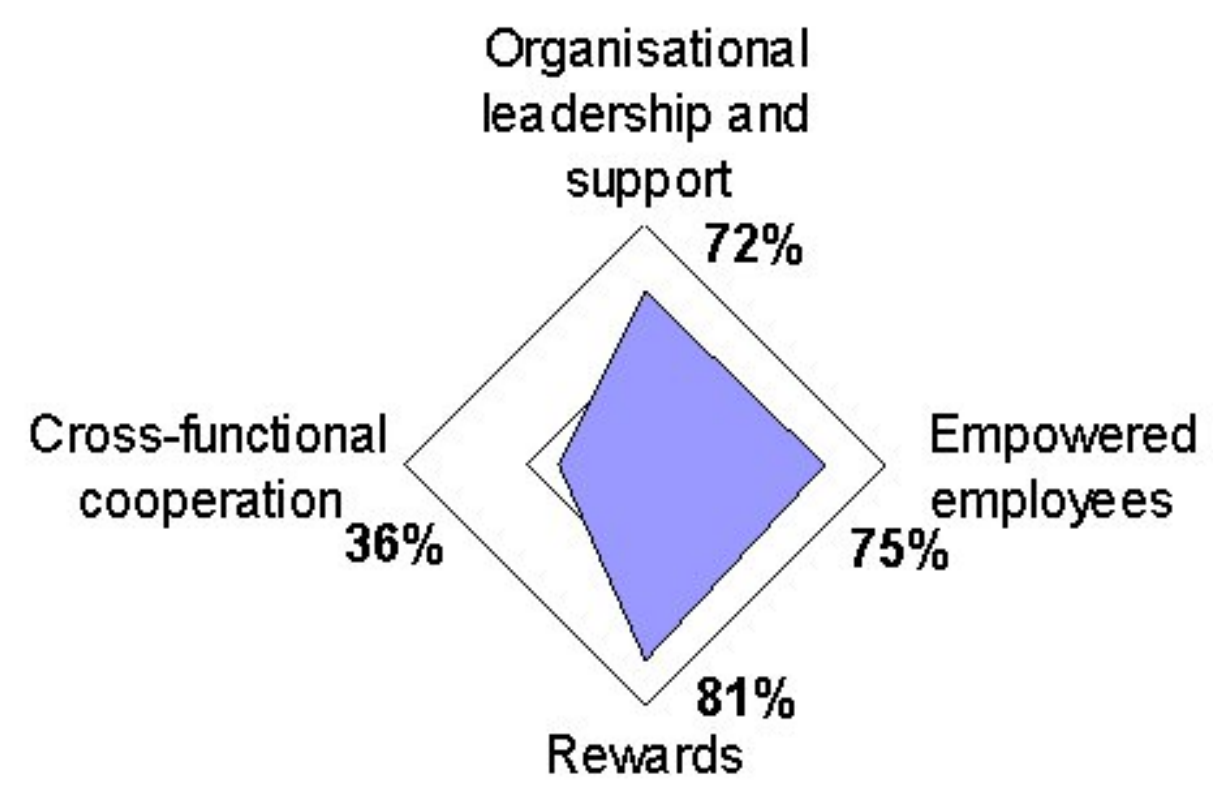

Figure 3 shows, as percentages, that rewards and recognition were related to respondents' job performance $(81 \%)$. The second dimension was 'empowered employees' $(6,76)$, where freedom was provided for respondents to decide how to accomplish their job responsibilities, with minimal supervision. The reason for the high level of empowerment $(75 \%)$ enjoyed by employees in the ICT sector can be ascribed to the fact that most employees can be classified as knowledge workers. Respondents also indicated that strong organizational leadership and support $(6,49)$ was provided for entrepreneurial activities; thereby implying that the organizational leadership in ICT firms was quick to implement new initiatives. Furthermore managers had experience of the innovation process and were supportive of entrepreneurial projects, providing financial support. An above average $72 \%$ was recorded on this dimension as shown in Figure 3. It is evident though that cross-functional cooperation between different departments within ICT firms were limited, with the lowest score $(3,27)$ reflected on this dimension. Reasons for this could be that many of the operational, technical or marketing staff might have focused on solving customer problems, while the administrative activities might have been separate departments, with limited interaction occurring between these departments.

\subsubsection{Performance}

The performance index was above the mid-point of the scale, with a value of 6,89 . Most responses viewed this index in a similar way, reflecting high levels of performance.

The next section describes how the various indicators of the entrepreneurial mindset were inter-related.

\subsection{Inter-relationship between indicators of entrepreneurial mindset}

The entrepreneurial mindset is especially reflected by EO posture of an enterprise. This section describes the association of $\mathrm{EO}$ with the number of initiatives implemented, the supportive climate for entrepreneurial activities and the way EO is related to the ICT firm performance index.

\subsubsection{Relationship between entrepreneurial orientation and e-business initiatives}


Table 3 shows the results of the correlation analysis of entrepreneurial orientation and the initiatives implemented in ICT companies. The results show that product and service initiatives are significantly correlated to EO at the $1 \%$ significance level. The relationship between process and business initiatives and $\mathrm{EO}$ is also statistically significant, but at the 5\% significance level.

Table 3 Correlation analysis of entrepreneurial orientation and e-business initiatives

\begin{tabular}{|l|c|c|}
\hline E-business initiatives & \multicolumn{2}{|c|}{ Entrepreneurial orientation } \\
\hline & Correlation coefficient (r) & Probability $(\boldsymbol{p})$ \\
\hline Product & 0,34 & $0,00^{* * *}$ \\
\hline Service & 0,27 & $0,00^{* * *}$ \\
\hline Process & 0,21 & $0,02 * *$ \\
\hline Business & 0,19 & $0,02 * *$ \\
\hline Overall & 0,34 & $0,00^{* * *}$ \\
\hline
\end{tabular}

Note: $* * *$ Significant at the $1 \%$ level

** Significant at the $5 \%$ level

The scatterplot in Figure 4 visually illustrates the statistically significant relationship between the number of entrepreneurial initiatives implemented and the EO of the ICT firms in the sample. The correlation coefficient of 0,34 does not indicate a strong relationship between EO and the number of entrepreneurial initiatives, and the respondents illustrated in Figure 4 do not cluster in close proximity to the trend line. However, this finding suggests that the more frequently firms implement entrepreneurial initiatives, the higher their EO is likely to be.

Figure 4 Scatter plot depicting the relationship between EO and entrepreneurial initiatives

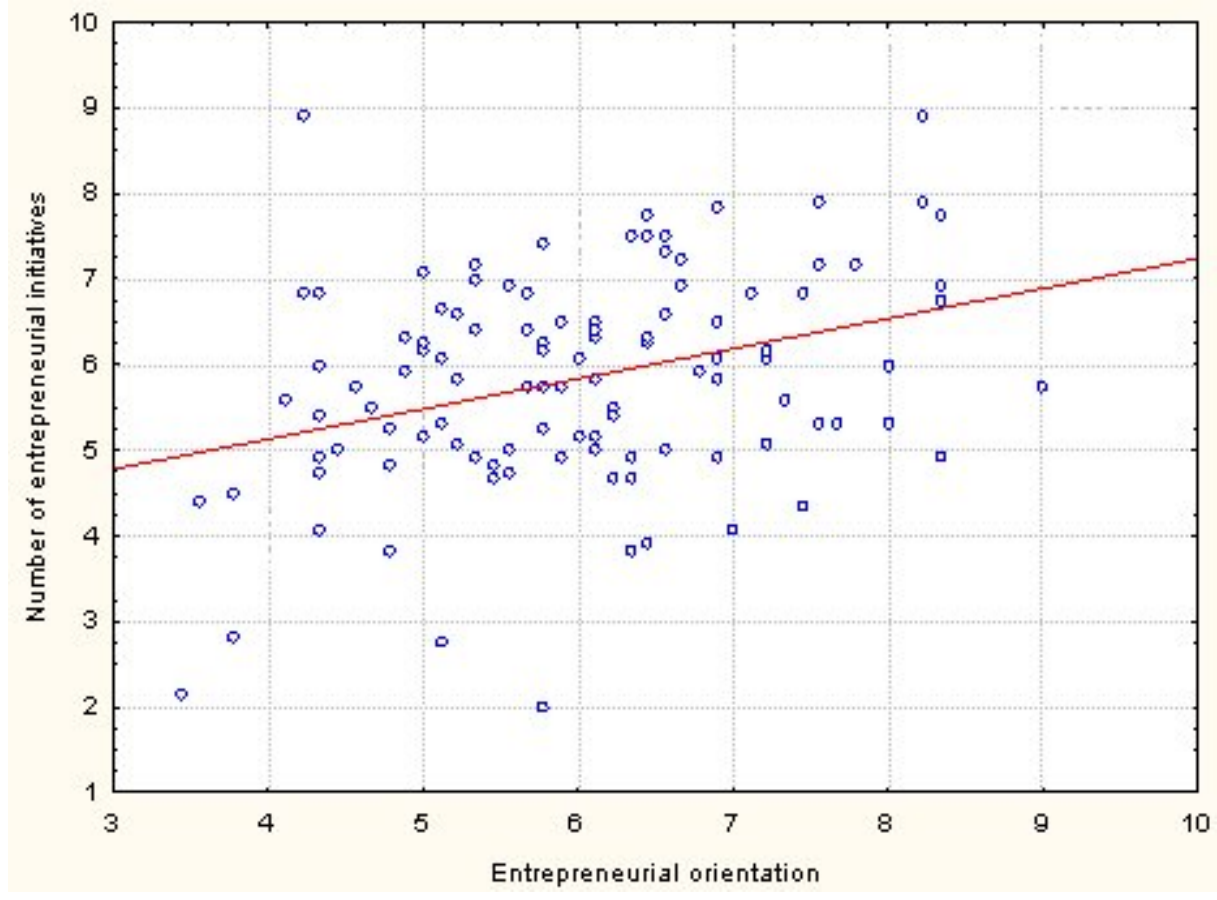

\subsubsection{Relationship between entrepreneurial orientation and a supportive climate}


The results of the correlation analysis between the various dimensions of $\mathrm{EO}$ and the supportive organizational climate are shown in Table 4. Organizational leadership and support show statistically significant correlations with innovativeness and risk-taking at the $5 \%$ significance level, and with pro-activeness at the $1 \%$ significance level. This dimension of a supportive climate also appears to be significantly related to the overall EO of firms. The rewards dimension is correlated to innovativeness $(0,30)$ at the $1 \%$ significance level, and also to the EO of firms. The empowered employees dimension is correlated $(0,24)$ with risktaking at the $1 \%$ significance level and correlated $(0,21)$ at the $5 \%$ significance level to EO. Cross-functional cooperation does not show correlations with one of the dimensions of EO.

Table 4 Correlation analysis of the dimensions of a supportive climate and EO

\begin{tabular}{|l|c|c|c|c|c|c|c|c|}
\hline & Innovativeness & Risk-taking & Proactiveness & \multicolumn{2}{|c|}{ EO } \\
\hline & $\boldsymbol{r}$ & $\boldsymbol{P}$ & $\boldsymbol{r}$ & $\boldsymbol{P}$ & $\boldsymbol{r}$ & $\boldsymbol{p}$ & $\boldsymbol{r}$ & $\boldsymbol{P}$ \\
\hline $\begin{array}{l}\text { Organizational leadership and } \\
\text { support }\end{array}$ & 0,21 & $0,01^{* *}$ & 0,21 & $0,01^{* *}$ & 0,25 & $0,00^{* * *}$ & 0,30 & $0,00^{* * *}$ \\
\hline Rewards & 0,30 & $0,00^{* * *}$ & 0,11 & 0,20 & 0,14 & 0,08 & 0,24 & $0,00^{* * *}$ \\
\hline Empowered employees & 0,12 & 0,15 & 0,24 & $0,00^{* * *}$ & 0,09 & 0,29 & 0,21 & $0,01 * *$ \\
\hline Cross-functional cooperation & 0,14 & 0,09 & 0,13 & 0,13 & 0,04 & 0,64 & 0,14 & 0,08 \\
\hline Supportive climate & 0,30 & $0,00^{* * *}$ & 0,26 & $0,00^{* * *}$ & 0,21 & $0,01 * *$ & 0,35 & $0,00^{* * *}$ \\
\hline
\end{tabular}

Note: *** Significant at the $1 \%$ level ** Significant at the $5 \%$ level

The results in Table 4 suggest that three dimensions of a supportive climate is associated with higher levels of EO, namely organizational leadership and support, rewards and empowered employees. Interestingly, organizational leadership and support is correlated to each dimension of EO, namely innovativeness, risk-taking and pro-activeness, but rewards is correlated to innovativeness, while empowered employees is correlated to risk-taking. These results imply that each of the three dimensions is needed to promote EO and an entrepreneurial mindset in turn.

\subsubsection{Relationship between entrepreneurial orientation and performance}

Figure 5 depicts the relationship between EO and financial e-business performance for ICT firms in the sample. The data from the study show that there is a weak positive relationship between EO and financial performance at the 1\% significance level. Although the correlation coefficient of 0,27 does not indicate a strong relationship, the relationship is supported by the literature. Additionally, financial e-business performance is influenced by several other factors such as the technical infrastructure, staff capabilities, learning effects and obstacles to implementation among others. Several authors (Erasmus and Scheepers 2008; Goosen 2002; Wiklund 1999) have shown that the relationship between EO and performance needs to be viewed longitudinally.

Figure 5 Scatterplot illustrating the relationship between EO and e-business performance 


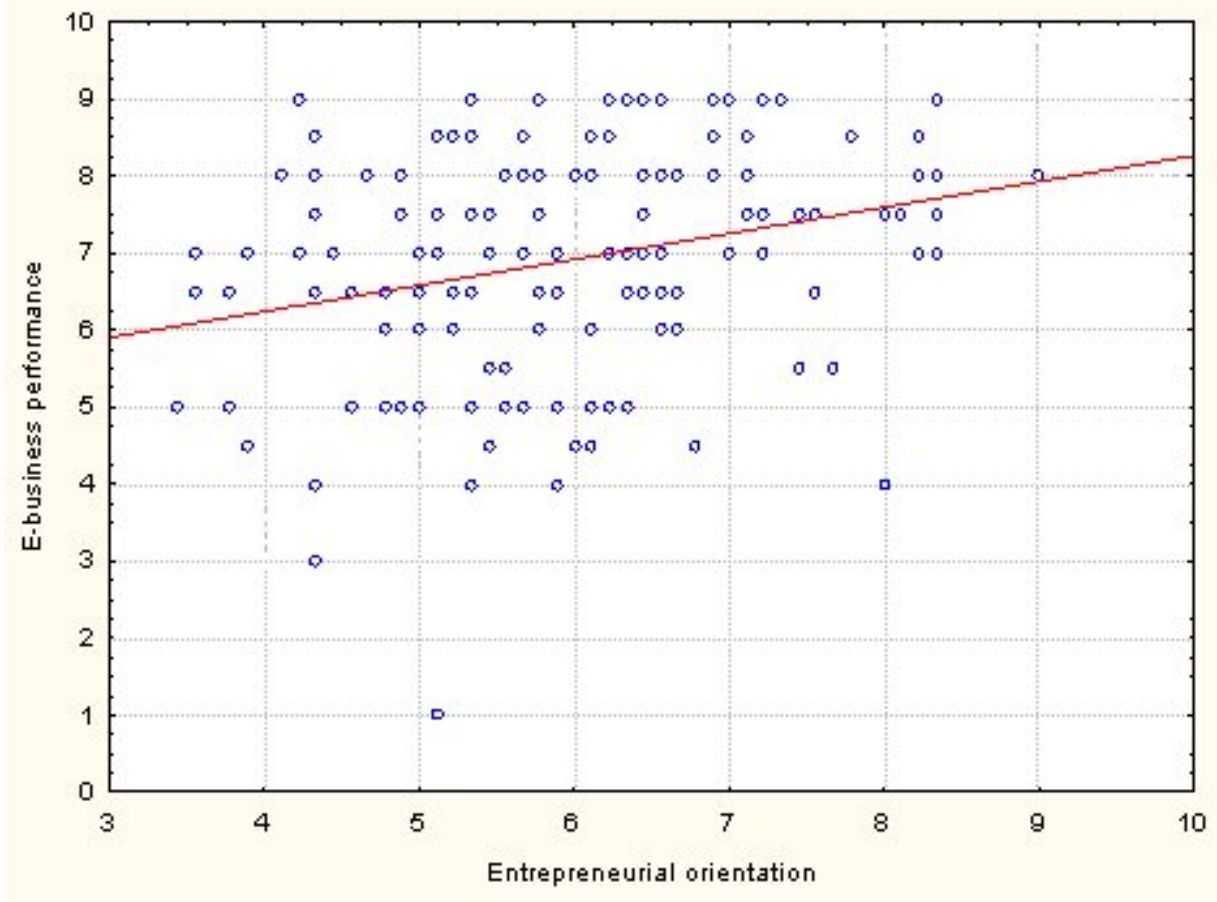

$\underline{\text { top }}$

\section{Recommendations and conclusions}

The purpose of this article is to describe the entrepreneurial mindset of ICT firms operating in South Africa.

The entrepreneurial mindset of ICT firms was assessed by looking at three indicators: EO, ebusiness initiatives and the organizational climate within firms. The findings indicate that ICT firms could be regarded as entrepreneurial, assessed on their EO. Firms in the sample showed a high propensity towards innovative and proactive behaviour, while displaying a moderate risk-taking orientation. Frequent e-business initiatives were implemented by firms in the sample, especially new e-business products, services and processes. Fewer firms focused on sourcing new clients and markets, which could be ascribed to limited resources. The organizational climate within ICT firms was generally supportive of initiatives. Rewards for innovation, empowered employees and organizational leadership and support prevailed within ICT firms; however it appears that little cross-functional cooperation between different departments within ICT firms occurred. This finding is contradictory to the literature. Reasons for the lack of cross-functional cooperation could be that operational staff focused on solving customer problems, while having little contact with administrative staff.

The inter-relationship between these indicators provided a more comprehensive view of the entrepreneurial mindset. The EO of firms was significantly associated with the incidence of e-business initiatives, suggesting that the more frequently firms implemented entrepreneurial initiatives, the higher their EO was likely to be. Organizational leadership and support, rewards and empowered employees were significantly related to higher EO levels. Further analysis also revealed that a relationship existed between EO and financial performance, as the literature suggests. It is expected that the relationship between EO and financial performance needs to be viewed longitudinally, as suggested by Goosen (2002).

Nevertheless, caution should be exercised when generalizing these results, since limitations on account of the research design may have influenced the findings. Resource limitations only allowed for data collection of one respondent per firm. It is suggested that future 
research triangulates the views of one respondent with secondary sources, or that multiple respondents be used. Furthermore, entrepreneurship can be applied to many different aspects within a firm, while this research only focused on e-business initiatives. Future research should test these findings across departments, sectors, firm size and age. Other avenues for further research are to examine the influence of external business conditions on the entrepreneurial mindset of firms, and the role of the individual within the process relative to the role of organizational factors should be studied.

Despite the limitations, recommendations that have both practical and academic relevance can be made. The results suggest that the entrepreneurial mindset of firms can be assessed by three indicators: EO, e-business initiatives implemented and the organizational climate. Firms that set increased targets for entrepreneurial initiatives should measure their progress towards these targets by assessing their entrepreneurial mindset. It is recommended that a firm increases its entrepreneurial mindset by firstly providing a supportive organizational climate within which employees can function. Specifically managers should provide leadership and support for initiatives, provide rewards and empower their employees. In this type of climate, more initiatives could be implemented, which should increase a firm's entrepreneurial orientation. One of the main benefits of an entrepreneurial mindset appears to be increased financial performance.

To conclude, ICT firms in South Africa can be described as entrepreneurial based on an assessment of their entrepreneurial mindset. These firms displayed high levels of EO, regularly implemented new e-business initiatives and created a supportive organizational climate within which their employees could function. In this way, ICT firms should have been able to differentiate themselves and increased their organizational competitiveness.

\section{Acknowledgements}

Support for the research study, on which this article is based, was provided by the National Research Foundation of South Africa and Stellenbosch University. The views expressed in this article in no way reflect the views or opinions of these two institutions. Suggestions from colleagues of the Centre for Higher and Adult Education at Stellenbosch University on earlier drafts of this article are highly appreciated.

\section{References}

Adonisi, M. 2003. The relationship between corporate entrepreneurship, market orientation, organisational flexibility and job satisfaction. Unpublished doctoral dissertation. University of Pretoria.

Anandji, C. 2006. Management accounting glossary. [Online]. Available WWW: http://services.eliteral.com/glossary/managerial-accounting-glossary.php (Accessed 5 May 2007).

Antoncic, B. and Hisrich, R.D. 2001. Intrapreneurship: construct refinement and crosscultural validation. Journal of Business Venturing 16:495-527.

Barringer, B.R. and Ireland, D.R. 2008. Entrepreneurship: successfully launching new ventures. Upper Saddle River, New Jersey: Pearson Prentice Hall. 
Birch, D.L. 1987. Job creation in America. New York: The Free Press.

Brown, S.L. and Eisenhardt, K.M. 1995. Product development: past research, present findings, and future directions. Academy of Management Review 20:343-378.

Burgelman, R. 1983. An empirical evaluation of the internal corporate venturing process. Administrative Science Quarterly 28:223-244.

Burgelman, R.A. 1984. Design for corporate entrepreneurship in established firms. California Management Review 16(3):154-166.

Busenitz, L.W., West III, G.P., Shepherd, D., Nelson, T., Chandler, G.N. and Zacharakis, A. 2003. Entrepreneurship research in emergence: past trends and future directions. Journal of Management 29(3):285-308.

Chandler, G.N., Keller, C. and Lyon, D.W. 2000. Unravelling the determinants and consequences of an innovation-supportive organisational culture. Entrepreneurship Theory \& Practice 25(1):59-77.

Covin, J.G. and Slevin, D.P. 1989. Strategic management of small firms in hostile and benign environments. Strategic Management Journal 10:75-87.

Covin, J.G. and Slevin, D.P. 1991. A conceptual model of entrepreneurship as firm behaviour. Entrepreneurship Theory and Practice 16(1):7-25.

Damanpour, F. 1991. Organisational innovation: a meta-analysis of effects of determinant and moderators. Academy of Management Journal 34:55-390.

Davidsson, P., 1989. Entrepreneurship and after? A study of growth willingness in small firms. Journal of Business Venturing 4(3): 211-226.

Denison, D.R. 1996. What is the difference between organizational culture and organizational climate? A native's point of view on a decade of paradigm wars. Academy of Management Review 21(3):619-654.

Department of Science and Technology. 2002. South Africa's National Research and Development Strategy. [Online]. Available WWW:

http://www.info.gov.za/otherdocs/2002/rd_strat.pdf (Accessed 25 August 2006).

Dhilwayo, S. and Van Vuuren, J.J. 2007. The strategic entrepreneurial thinking imperative. Acta Commercii 7:123-134.

Drucker, P.F. 2007. The definitive Drucker: the final word from the father of modern management. New York: McGraw-Hill.

Dutta, S. and Mia, I. 2007. The global information technology report 2006-2007: connected to the networked economy. New York: Palgrave MacMillan.

Elenkov, D.S., Judge, W. and Wright, P. 2005. Strategic leadership and executive innovation influence: an international multi-cluster comparative study. Strategic Management Journal 26:665-682.

Erasmus, P.D. and Scheepers, M.J. 2008. The relationship between corporate entrepreneurship and value based financial performance measures. Managing Global 
Transitions (in press).

Gemünden, H.G., Salomo, S. and Krieger, A. 2005. The influence of project autonomy on project success. International Journal of Project Management 23:366-373.

Goosen, G.J. 2002. Key factor intrapreneurship: the development of a systems model to facilitate the perpetuation of entrepreneurship in large South African organisations. Unpublished Ph.D. thesis. University of Stellenbosch.

Goosen, G.J., De Coning, T.J. and Smit, E.V.D.M. 2002. Corporate entrepreneurship and financial performance: the role of management. South African Journal of Business Management 33(4):21-27.

Govender, M. 1998. Conducting an entrepreneurial audit. Unpublished MBA thesis. University of Cape Town.

Gudmundson, D., Tower, C.B. and Hartman, E.A. 2003. Innovation in small businesses: culture and ownership structure do matter. Journal of Developmental Entrepreneurship 8 (1):1-17

Hills, G. and LaForge, R. 1992. Research at the marketing interface to advance entrepreneurship theory. Entrepreneurship Theory and Practice 16 (Spring):33-59.

Hornsby, J.S., Kuratko, D.F. and Zahra, S.A. 2002. Middle managers' perception of the internal environment for corporate entrepreneurship: assessing a measurement scale. Journal of Business Venturing 17:253-273.

ISETT Seta, 2007. Sector skills plan 20050 2010: Version 2.0. [Online] Available WWW http://www.isett.org.za/incASP/frame.asp?theSection=/ssp/default.asp (Accessed 10 November 2007).

Knight, G.A. 1997. Cross-cultural reliability and validity of a scale to measure firm entrepreneurial orientation. Journal of Business Venturing 12(3):213-225.

Kreiser, P., Marino, L. and Weaver, L.M. 2002. Assessing the relationship between entrepreneurial orientation, the external environment and firm performance. Frontiers of Entrepreneurship Research: Babson [Online]. Available WWW:

http://www.babson;edu/entrep/fer/Babson2002/XVII/XVII_S4/SVII_S4_nav.html (Accessed 12 June 2006).

Kuratko, D.F. and Hodgetts, R.M. 2004. Entrepreneurship: theory, process and practice. Sixth edition. USA: Thompson South-Western.

Kuratko, D.F., Montagno, R.V. and Hornsby, J.S. 1990. Developing an intrapreneurial assessment instrument for an effective corporate entrepreneurial environment. Strategic Management Journal 11:49-58.

Lumpkin, G.T. and Dess, G.G. 1996. Clarifying entrepreneurial orientation construct and linking it to performance. Academy of Management Review 21(1):135-172.

Malone, M.S. 2001. The valley of heart's delight: a Silicon Valley notebook, 1963-2001. New Jersey: John Wiley and Sons.

Mbeki, T. 2002. The context for the National R\&D Strategy. In: DST, 2002 National 
Research \& Development Strategy [Online]. Available WWW:

http://www.dst.gov.za/legislation_policies/strategic_reps/sa_nat_rd_strat.htm (Accessed: 18 January 2006).

McGrath, R.G. and MacMillan, I, 2000. The entrepreneurial mindset. Boston: Harvard Business School Publishing.

Miller, D. 1983. The correlates of entrepreneurship in three types of firms. Management Science 29:770-791.

Miller, D. and Friesen, P. 1983. Strategic-making and environment: the third link. Strategic Management Journal 4(3):221-235.

Minniti, M., Bygrave, W.D. and Autio, E. 2006. Global entrepreneurship monitor 2005 executive report. Babson College and London School of Business.

Moodley, S. 2002. E-business in the South African apparel sector: a utopian vision of efficiency? The Developing Economies XL(1):67-100.

Morris, M.H. 1998. Entrepreneurial intensity: sustainable advantages for individuals, organisations and societies. Quorum Books: Westport.

Morris, M.H. and Kuratko, D.F. 2002. Corporate entrepreneurship. Harcourt College Publishers: Orlando, Florida.

Morris, M.H., Kuratko, D.F. and Covin, J.G. 2008. Corporate entrepreneurship and innovation. Mason, Ohio: Thomson South-Western.

Morris, M.H., Schindehutte, M. and Allen, J. 2005. The entrepreneur's business model: toward a unified perspective. Journal of Business Research 58(6):726-735.

Morris, M.H. and Sexton, D.L. 1996. The concept of entrepreneurial intensity: implications for company performance. Journal of Business Research 36:5-13.

NRF, National Research Foundation, 2004. Focus area: economic growth and international competitiveness. [Online] Available WWW: http://www.nrf.ac.za/focusareas/index.stm (Accessed 11 July 2004).

Ngo, H-Y and Lau, C-M. 2004. The HR system, organizational culture and product innovation. International Business Review 13(6):685-703.

Pinchot III, G. 1999. Intrapreneuring: you don't have to leave the corporation to become an entrepreneur. New York: Harper \& Row.

Scheepers, M.J. 2005. How innovative are South African firms? In: Von Broembsen, M., Wood, E. and Herrington, M. Global entrepreneurship monitor: South African report 2005. Cape Town: Centre for Innovation and Entrepreneurship: UCT Graduate School of Business.

Scheepers, M.J. and Hough, J. 2004. Corporate entrepreneurship in the knowledge society: a South African perspective. Paper presented at the SAIMS Conference, 27-29 September, Cape Town.

Sekaran, U. 1992. Research methods for business: a skill building approach. Second edition. John Wiley: New York. 
Senges, M. 2007. Knowledge entrepreneurship in universities: practice and strategy of Internet based innovation appropriation [Online]. Available WWW:

http://knowledgeentrepreneur.com (Accessed: 29 May 2008).

Shane, S. and Venkataraman, S. 2000. The promise of entrepreneurship as a field of research. Academy of Management Review 25(1):217-226.

Sharma, P. and Chrisman, J.J. 1999. Towards a reconciliation of the definitional issues in the field of corporate entrepreneurship. Entrepreneurship Theory and Practice 23(3):11-27.

StatSoft, INC 2007. STATISTICA (data analysis software system), version 7.1. www.statsoft.com.

Stevenson, H.H. and Jarillo, J.C. 1990. A paradigm of entrepreneurship: entrepreneurship management. Strategic Management Journal 11(Summer Special Issue):17-27.

Tagiuri, R. and Litwin, G. (eds.). 1968. Organizational climate: explorations of a concept. Boston: Harvard Business School.

Vise, D.A. 2005. The Google story. Great Britain: MacMillan.

Wielemaker, M. 2003. Managing initiatives: a synthesis of the conditioning and knowledgecreating view. Unpublished PhD thesis. Erasmus University Rotterdam.

Wiklund, J. 1999. The sustainability of the entrepreneurial-orientation performance relationship. Entrepreneurship Theory \& Practice 1999(Fall):37-48.

$\mathrm{Yu}, \mathrm{J}$. and Cooper, H. 1983. A quantitative review of research design effects on response rates to questionnaires. Journal of Marketing Research (Feb):36-44.

Zahra, S.A. 1991. Predictors and financial outcomes of corporate entrepreneurship: an exploratory study. Journal of Business Venturing 6(4):259-285.

Zahra, S.A. 1993. Environment, corporate entrepreneurship and financial performance: a taxonomic approach. Journal of Business Venturing 8(4) pp.319-340.

Zahra, S.A. 2007. Contextualising theory building in entrepreneurship research. Journal of Business Venturing 22(3):443-452

Zahra, S.A. and Bogner, W.C. 1999. Technology strategy and software new ventures' performance: exploring the moderating effect of the competitive environment. Journal of Business Venturing 15:135-173.

Zahra, S.A. and Covin, G. 1995. Contextual influences on the corporate entrepreneurshipperformance relationship: a longitudinal analysis. Journal of Business Venturing 10:43-58. 
ISSN 1560-683X

Published by InterWord Communications for Department of Information and Knowledge Management, University of Johannesburg 